\title{
BEHAVIOUR OF BIOPOLISHING ON DYEABILITY AND CERTAIN PROPERTIES OF COTTON FABRICS
}

\author{
Kiro Mojsov ${ }^{1 *}$, Aco Janevski ', Darko Andronikov', Sonja Jordeva', \\ Marija Kertakova', Saska Golomeova', Stevan Gaber ${ }^{2}$, Ivan Ignjatov ${ }^{2}$
}

\author{
${ }^{1}$ University "Goce Delchev", Faculty of Technology, Shtip, Macedonia \\ 2 University "Goce Delchev", Faculty of Economics, Shtip, Macedonia \\ *e-mail: kiro.mojsov@ugd.edu.mk
}

Review paper

UDC: 677.21 .027 .615 .1

DOI: $10.5937 /$ tekstind $1901020 \mathrm{M}$

\begin{abstract}
Conventional chemical processes are generally severe and fibre damage may occur. Enzymes are characterized by their ability to operate under mild conditions and as a result processes can be carried out without further damaging the fibers. Enzymes are also readily biodegradable and therefore potentially harmless and environmentally friendly. Biopolishing enzymes used in biopolishing, offers a number of benefits such as improvement in pill resistance, superior colour brightness, softness and cooler feel. Biopolishing treatment, given to the cotton fabrics using cellulases, often influences dyebility and certain physical properties of the fabrics after treatments. This work represents a review of behavior of cellulase treatment on dyeability and various properties of cotton fabrics.
\end{abstract}

Keywords: biopolishing, cotton fabrics, cellulase, eco-friendly characteristics.

\section{PONAŠANJE BIOPOLIRANJA NA OBOJENOST I ODREĐENA SVOJSTVA PAMUČNIH TKANINA}

Apstrakt: Konvencionalni hemijski procesi su generalno ozbiljni i mogu da oštete vlakana. Enzimi se odlikuju svojom sposobnošću da rade pod blagim uslovima i kao rezultat toga, procesi se mogu odvijati bez daljeg oštećenja vlakana. Enzimi su takođe lako biorazgradivi i stoga potencijalno bezopasni i ekološki prihvatljivi. Biopolirani enzimi koji se koriste u biopoliranju, nude brojne pogodnosti kao što su poboljšanje otpornosti na piling, superiorna osvetljenost boje, mekoća i hladniji osećaj. Tretman biopoliranjem, koji se daje pamučnim tkaninama od celulaze, često utiče na obojenost i određene fizičke osobine tkanina nakon tretmana. Ovaj rad predstavlja pregled ponašanja celulaznog tretmana na obojenost i različita svojstva pamučnih tkanina.

Ključne riječi: biopoliranje, pamučne tkanine, celulaze, ekološke karakteristike.

\section{INTRODUCTION}

Biotechnology is defined as application of biological organisms, systems and processes to manufacturing and processing industries. This is reflected in ability of enzymes to recognize other biological systems and to catalyse a vast range of specific chemical reactions under moderate and much more economic conditions [1]. Recent advances in biofinishing of cellulosic fabrics have led to multiple improvements of surface properties. The main objective of biofinishing is to upgrade the fabric by removing the protruding fibers. The conventional methods are temporary, potentially toxic, and fibers return to the surface after a few washings and form fuzz. The fuzz on the surface of the fabrics constitutes the major reason for customer dissatisfaction. However, by using enzymes in the finishing process, the protruding fibers can be permanently removed from the fabric thus eliminating the fuzz. The enzyme treatment not only keeps the fabric looking new after repeated washings, but enhances 
feel, color, softness and drapeability which translates into a higher quality textile or apparel product $[2,3]$.

Enzymes are biological catalysts. A catalyst is any substance which makes a chemical reaction go faster, without itself being changed. All enzymes are made of protein and because they are sensitive to heat, $\mathrm{pH}$ and heavy metal ions.

Hydrolytic treatment of cellulosic fabrics and garments with cellulases has become a common treatment step in textile processing [4]. Cellulase preparations consist of several different cellulolytic enzymes which act synergistically in hydrolysing cellulose to glucose.

Cotton fabric has several impurities such as fats and waxes, pectinous substances, proteinous matter, ash etc. In order to remove these impurities, scouring of cotton fabric is normally carried out with strong alkali at high temperature and for longer duration. Although, this treatment gives very good results, one of the problems is high loss in weight of cellulosic material. On the other hand, bleaching removes any unwanted colour from the fibres. In the enzymatic treatment, producers of textile enzymes recommend dosages of approximately 0.05 to $6 \%$ of cellulase preparation on garment weight [5].

Biopolishing is an important finishing treatment carried out on cellulosic fabrics using acid cellulases to achieve improvement in gloss, luminosity of colours and resistance to pilling, cooler feel and clear surface [6].

Biopolishing of cotton fabrics carried out, either before or after the dyeing process, has an influential role on dyeability of the fabrics. Bulky dye molecules used in cotton fabrics react only in the accessible regions of fibres, which are, also major parts of the substrates for enzyme hydrolysis during biopolishing. Extent of cellulase attack on dyed fabrics depends on molecular size of dyesand aggregation of dye molecules, besides the process conditions [7].

Cellulase pretreatment enhances penetration of alkali during scouring and increases the alkaline degradation of seed fragments in the subsequent process [8]. Presence of various components in the total cellulases plays a dominating role in altering surface morphology of the fibres [9].

Cellulases are inducible enzymes synthesized by a large diversity of microorganisms including both fungi and bacteriaduring theirgrowth on cellulosicmaterials. These microorganisms can be aerobic, anaerobic, mesophilic or thermophilic. Among them, the genera of Clostridium, Cellulomonas, Thermomonospora, Trichoderma, and Aspergillus are the most extensively studied cellulase producer [10].

\section{COTTON FIBRE AND HIS STRUCTURE}

Cotton, the seed hair of plants of the genus Gossypium, is the purest form of cellulose readily available in nature. It has many desirable fibre properties making it an important fibre for textile applications. Cotton is the most important of the raw materials for the textile industry. The cotton fibre is a single biological cell with a multilayer structure. The layers in the cell structure are, from the outside of the fiber to the inside, cuticle, primary wall, secondary wall, and lumen. These layers are different structurally and chemically [11].

The primary and secondary walls have different degrees of crystallinity, as well as different molecular chain orientations. The cuticle, composed of wax, proteins, and pectins, is $2.5 \%$ of the fiber weight and is amorphous. The primary wall is $2.5 \%$ of the fiber weight, has a crystallinity index of $30 \%$, and is composed of cellulose. The secondary wall is $91.5 \%$ of the fiber weight, has a crystallinity index of $70 \%$, and is composed of cellulose. The lumen is composed of protoplasmic residues [12].

Cotton cellulose consists of crystalline fibrils varying in complexity and length and connected by less organized amorphous regions with an average ratio of about two-thirds crystalline and one-third non-crystalline material, depending on the method of determination [13]. The chemical composition of cellulose is simple, consisting of anhydroglucose units joined by $\beta-1,4-$ glucosidic bonds to form linear polymeric chains.

\section{CELLULOSE AND CELLULASES}

Cellulose is considered as one of the most important sources of carbon on this planet. Agriculture wastes contain a high proportion of cellulosic matter which is easily decomposed by a combination of physical, chemical and biological processes. The major components of these are cellulose and hemicellulose $(75-80 \%)$ while lignin constitutes only $14 \%$. These wastes have been insufficiently disposed leading to environmental pollution. Recycling of agricultural residue can be achieved naturally and artificially by microorganisms. Aerobic organisms such as fungi, bacteria, and some anaerobic organisms have been shown to be able to degrade some constituents of these residues.

Cellulases are hydrolytic enzymes that catalyse the breakdown of cellulose to smaller oligosaccharides and finally glucose. Cellulases are enzymes which hydrolyze the $\beta-1,4-$ glycosidic linkage of cellulose 
and synthesized by microorganisms during their growth on cellulosic materials [14].

The commercially available cellulases are a mixture of enzymes: endogluconases, exogluconases and cellobiases. The application of cellulases in textile processing started in the late 1980s with denim finishing. Currently, in addition to biostoning, cellulases are also used to process cotton and other cellulose-based fibres. Cellulases are usually classified by the $\mathrm{pH}$ range in which they are more effective and, accordingly, acid cellulase, neutral cellulase and alkaline cellulase. Cellulases are inducible enzymes which are synthesized by microorganisms during their growth on cellulosic materials.

Cellulases were introduced in textile and laundry only a decade ago, they have now become the third largest group of enzymes used in these applications. Microbial cellulases find applications in textile industries as biostoning of jeans, biopolishing of textile fibers, improved fabrics quality, improved absorbance property of fibers, softening of garments, improved stability of cellulosic fabrics, removal of excess dye from fabrics etc. $[1,15]$. Bio-stoning and biopolishing are the best-known current textile applications of cellulases. Denim stonewash enzymes or denim enzymatic treatments has replaced traditionally used pumice stones since it is more environmentally friendly and reduces overall damage to the denim while still producing the "stone washed" which is still very popular today. The advantages in the replacement of pumice stones by a cellulose-based treatment include less damage of fibers, increased productivity of the machines, and less work-intensive and environment benign [19].

In Table 1 are given the applications of cellulases in the textile industry.

\section{BIOPOLISING AND DYEABILITY}

Biopolishing (de-pilling enzymes) is a biological process in which the cellulose acts on the surface of the fabric. The enzyme molecule is more than a thousand times larger than a water molecule and is therefore too large to penetrate the interior of a cotton fiber.

The objective of the process is elimination of micro fibrils of cotton through the action of cellulase enzyme. The acidic cellulases, when used in biopolishing, offers a number of benefits such as improve softness and water absorbance property of fibres, strongly reduce the tendency for pill formation, and provide a cleaner surface structure with less fuzz [20].

In the case of fabrics dyed with direct dyes, the efficiency of biopolishing is highly influenced by size, substantivity, molecular weight and concentration of dyes in the fabrics [21]. Fabrics dyed with reactive dyes of different reactive groups exhibit surface roughness after processing with crude cellulases, purified EG and $\mathrm{CBH}$, due to poor biopolishing effects compared to the undyed fabrics $[21,22]$. Presence of vat dyes does not influence the weight loss during cellulase treatment in many cases [7, 23]. In denim washing, acid cellulases are used in stonewashing, stoneless washing processes to impart various effects to the fabrics in terms of contrast, shade and smoothness [24].

\section{PROPERTIES OF BIOPOLISHED COTTON FABRICS}

Presence of various components in the total cellulases plays a dominating role in altering surface morphology of the fibres [9]. Adsorption of cellulases

Table 1: Cellulases in textile industry

\begin{tabular}{|c|c|c|c|}
\hline Enzyme & Function & Application & Reference \\
\hline $\begin{array}{c}\text { Cellulase, preferably } \\
\text { neutral and } \\
\text { endoglucanase rich }\end{array}$ & $\begin{array}{c}\text { Removal of excess dye from } \\
\text { denim fabrics; soften } \\
\text { the cotton fabrics without } \\
\text { damaging the fibre }\end{array}$ & $\begin{array}{c}\text { Bio-stoning of denim } \\
\text { fabrics; production of high } \\
\text { quality and environmentally } \\
\text { friendly washing powders }\end{array}$ & $\begin{array}{c}\text { Galante et al., 1998 } \\
\text { [16]; Godfrey, 1996 [17] }\end{array}$ \\
\hline $\begin{array}{c}\text { Cellulase, preferably } \\
\text { acid and } \\
\text { endoglucanase rich }\end{array}$ & $\begin{array}{c}\text { Removal of excess } \\
\text { microfibrils } \\
\text { from the surface of cotton } \\
\text { and non-denim fabrics }\end{array}$ & $\begin{array}{c}\text { Bio-polishing of cotton and } \\
\text { non-denim fabrics }\end{array}$ & $\begin{array}{c}\text { Galante et al., 1998 } \\
\text { [16]; Godfrey,1996 [17]; } \\
\text { Kumar et al.,1994 [18] }\end{array}$ \\
\hline $\begin{array}{c}\text { Cellulase, preferably } \\
\text { endoglucanase rich }\end{array}$ & $\begin{array}{c}\text { Restoration of softness and } \\
\text { colour brightness of cotton } \\
\text { fabrics }\end{array}$ & $\begin{array}{c}\text { Production of high quality } \\
\text { fabrics }\end{array}$ & $\begin{array}{c}\text { Galante et al., 1998 } \\
{[16] ; \text { Godfrey, 1996 [17]; }} \\
\text { Kumar et al., 1994 [18] }\end{array}$ \\
\hline
\end{tabular}


on the surface of substrates takes place immediately after the introduction and remains even after washing [25]. Cellulase treatments remove the corrugated spiral structures, causing erosion and longitudinal fissures [27].

Water absorbency and water retention properties of fabrics are modified after biopolishing [27]. Cellulase treated fabrics show higher energy dissipation under wet condition. Wettability of the fabrics after biopolishing improves by $35-85 \%$ depending upon construction of the fabrics [28]. Enzyme treatment of cotton fabrics increases transverse swelling of fibres by $14 \%$. Water retention capacity of cotton fabrics increases by $24-28 \%$, due to splitting of microfibrils [29].

Changes in the degree of polymerization, degree of crystallinity and weight loss of fabrics significantly influence tensile properties in terms of tensile elongation, tensile and compressive resilience, shear rigidity, hysteresis and surface friction [30]. Strength of dyed fabrics appears to be better (less strength loss) than that of fabrics treated with enzymes and then dyed, though the differences are not significant [31].

A linear relationship exists between depilling and weight losses for total cellulase and endo-rich cellulase [28]. Slow kinetics of enzymatic degradation of crystalline cotton celluloses allows handle of the fabrics to be improved without excessively damaging the fabrics [32]. Harshness produced by the alkaline mercerization can be counteracted by cellulase treatment, while soft handle of liquid ammonia treated samples can further be enhanced by the cellulase treatment. Cellulase treatment lowers the tensile and compressional energy, which essentially means improved handle [32].

\section{CONCLUSIONS}

The progress in biotechnology of cellulases and related enzymes is truly remarkable and attracting worldwide attention. New enzymes with high specific activity, increased reaction speed, and tolerance to more extreme temperatures and $\mathrm{pH}$ could result in development of continuous processes. The textile industry can greatly benefit from the expanded use of these enzymes as non-toxic, environmentally friendly compounds. Textile processing industry is characterized by high consumption of energy and resources and time consuming processes.

Biopolishing of cotton fabrics offers unmatched results that can otherwise be achieved using chemical finishes. Effective enzyme treatment, which depended on fiber content and treatment level, resulted in progressive weight loss. Biopolishing employs ba- sically the same cellulose action to remove fine surface fuzz and fibrils from cotton and viscose fabrics. The polishing action thus achieved helps to eliminate pilling and provides better print definition, colour brightness, surface texture, drapeability, and softness without any loss of absorbency.

\section{REFERENCES}

[1] Mojsov, K. (2014). Biopolishing enzymes and their applications in textiles: A review. Tekstilna industrija, 61 (2), 20-24.

[2] Hemmpel, W. H. (1991). The Surface Modification of Woven and Knitted Cellulosic Fibre Fabrics by Enzymatic Degradation. International Textile Bulletin Dyeing/Printing/Finishing, 37(3), 5-14.

[3] Mojsov, K., Janevski, A., Andronikov, D., Gaber, S. (2017). Determination of weight loss of cotton fabrics in enzymatic treatment. Tekstilna industrija, 64 (1), 44-48.

[4] Gübitz, G. M., Cavaco-Paulo, A. (2001). Biotechnology in the textile industry-perspectives for the new millennium. Journal of Biotechnology, 89(2-3), 89-90.

[5] Heikinheimo, L. (2002). Trichoderma reesei cellulases in processing of cotton. VTT publications, Finland, 28-29.

[6] Manikam, M,M., Prasad, G.J. (2004). Colourage, 52(10), 41-47.

[7] Gusakov, A. V., Sinitsyn, A. P., Berlin, A. G., Markov, A. V. (2007). Surface hydrophobic amino acid residues in cellulase molecules as a structural factor responsible for their high denim washing performance. Enzyme and Microbial Technology, 27, 664-671.

[8] Li, S., Jin, D. J. (2003). Use of enzymes in dyeing and fnishing. Textile Asia, 34, 52-55.

[9] Obturk, H. B., Bechtold, T. (2008). Splitting tendency of cellulosic fibres - part III tendency of viscose and modal fibres. Cellulose, 15, 101-109.

[10] Sun, Y., and Cheng, J. (2002). Hydrolysis of lignocellulosic materials for ethanol production: a review, Bioresource Technology, 83(1),1-11.

[11] Boylston, E. K., Hebert Usda, J. J. (1995). The Primary Wall of Cotton Fibers. Textile Research Journal, 65 (7), 429-431.

[12] Li, Y., Hardin, I.R., Enzymatic Scouring of Cotton: Effects on Structure and Properties. Textile Chem- 
ist and Colorist \& American Dyestuff Reporter, 29 (8), 71-76 (1997).

[13] Morton, W., Hearle, J. (1997). Natural-cellulose fibres. In Physical Properties of Textile Fibers. The Textile Institute, Manchester, 38-41.

[14] Nallankilli, G. (1992). Enzymes in Textile wet processing, Textile Industry and Trade Journal, 30(1), 5155.

[15] Xia, L., Cen, P. (1999). Cellulase production by solid state fermentation on lignocellulosic waste from the xylose industry, Process Biochem, 34, 909-912.

[16] Galante, Y.M., De Conti, A., Monteverdi, R. (1998). Application of Trichoderma enzymes in textile industry, in Trichoderma \& Gliocladium-Enzymes, Biological Control and Commercial Applications, vol.2, edited by Harman, G.F. \& Kubicek, C.P., (Taylor \& Francis, London), 311-326.

[17] Godfrey, T., Textiles. In: Godfrey, T., West, S. (1996) editors. Industrial enzymology, 2nd ed. London: Macmillan Press, 360-371.

[18] Kumar, A., Lepola, M., Purtell, C. (1994). Enzyme finishing of man-made cellulosic fabrics. Textile Chem Colourist, 26, 25-28.

[19] Bhat, M.K. (2000). Cellulases and related enzymes in biotechnology, Biotechnol Adv, 18, 355-383.

[20] Sreenath, H. K., Shah, A. B., Yang, V. W., Gharia, M. M., Jeffries, T. W. (1996). Enzymatic polishing of jute/ cotton blended fabrics, Journal of Fermentation and Bioengineering, 81(1), 18-20.

[21] Prabhu, H. G., Arputharaj, A. (2003). Studies on cellulase treatment on cotton. Colourage, 50, 31-34.

[22] Yamade, M., Amano, Y., Horikawa, E., Nozaki, K., Kanda, T. (2005). Mode of action of cellulase on dyed cotton with a reactive dye. Bioscience Biotechnology and Biochemistry, 69(1), 45-50.

[23] Arja, M. O., Londerborough, J., Joutsjoki, V., Rajia, L., Jari, V., (2004). Three cellulases from Melanocarpus albomyces for textile treatment at neutral $\mathrm{pH}$. Enzyme and Microbial Technology, 34, 332-341.

[24] Schmitt, B., Prasad, A. K. (1998). Update of indigo denim washing. Colourage (10), 20-24.

[25] Azevedo, H., Bishop, D., Paulo, A. C. (2002). Possibilities for recycling cellulases after use in cotton processing. Applied Biochemistry and Biotechnology, 101, 61-75.
[26] Traore, M. K., Diller, G. B. (1999). Influence of wetting agent and agitation on enzymatic hydrolysis of cotton. Textile Chemist and Colorists \& American Dyestuff Reporter, 1(4), 21-56.

[27] Cuissinat, C., Navard, P. (2008). Swelling and dissolution of cellulose - part III plant fibres in aqueous system. Cellulose, 15, 67-74.

[28] Raje, C. R., Gurjar, M., Kawlekar, S. R. (2001). Finishing of cotton fabrics with cellulase enzymes. Indian Textile Journal, 112, 37-41.

[29] Radhakrishnaiah, P., Meng, X., Huang, G., Diller, G. B., Walsh, W. K. (1999) Mechanical agitation of cotton fabrics during enzyme treatment and its effect on tactile properties. Textile Research Journal, 69, 708-713.

[30] Hebeish, A., Ibrahim, N. A. (2007). The impact of frontier sciences on textile industry. Colourage, 54, 41-55.

[31] Blanchard, E. J., Graves, E. E., Batiste, S. L. (2000). Enzymatic hydrolysis of modified cotton. Textile Chemists and Colorists \& American Dyestuff Reporter, 32, 37-41.

[32] Gulrajani, M. L., Dayal, A., Chakraborty, M. (1998). Kawabata evaluation of enzyme treated cotton knitted fabrics. Indian Journal of Fibre and Textile Research, 23, 160-164.

Rad primljen: 17.11.2018.

Rad prihvaćen: 11.01.2019. 